\title{
Effects of whey and molasses as silage additives on potato hash silage quality and growth performance of lambs
}

\author{
B.D. Nkosi ${ }^{\text {\#\# }}$ and R. Meeske ${ }^{2}$ \\ ${ }^{1}$ ARC-LBD: Animal Production Institute, P/Bag x 2, Irene 0062, South Africa \\ ${ }^{2}$ Western Cape Department of Agriculture, P.O. Box 249, George 6530, South Africa
}

\begin{abstract}
The aim of the study was to determine the effect of whey or molasses on the fermentation quality when added to potato hash silage. In addition, lamb performance, digestibility and feed intake of diets containing potato hash silage were compared with a diet containing maize silage (MSd). Potato hash silage (treated with no additive, or whey, or molasses) and MS were produced in $210 \mathrm{~L}$ drums for 90 days and the fermentation quality of the silages was determined thereafter. Diets were formulated and fed ad libitum to 32 South African Dorper lambs $(23.5 \pm 0.873 \mathrm{~kg}$ live weight $)$ for 63 days. A digestibility study was conducted during the last week of the study. The untreated potato hash silage (UPHS) was poorly fermented as indicated by higher concentrations of butyric acid, ammonia- $\mathrm{N}$ and $\mathrm{pH}$ compared to the other silages. Higher dry matter intake (DMI) and daily weight gains $(218$ and $250 \mathrm{~g} / \mathrm{d})$ were obtained with MSd and molasses treated potato hash silage diet (MPHSd) compared to the other diets. Nutrient digestibility was lower in the UPHS diet compared to the other dietary treatments. It was concluded that the fermentation quality of potato hash was improved with the addition of whey and molasses. Furthermore, growth performance was higher with the MSd and MPHSd than of the other treatments, suggesting that MPHSd can safely replace MSd in a lamb diet at a dietary inclusion level of $20 \%$ without any adverse effect on animal performance.
\end{abstract}

Keywords: Digestibility, dry matter, fermentation, intake, maize silage

${ }^{\#}$ Corresponding author. E-mail: DNkosi@arc.agric.za

\section{Introduction}

A major constraint to profitable livestock production under resource poor farmers in the Gauteng Province (South Africa) is the limited feed supply throughout the year (GADS, 2006). This province is experiencing a rapid growth in human population coupled with high demands for housing which limits availability of land suitable for fodder production. The utilization of less traditional feeds such as byproducts combined with roughage sources may provide farmers with a variety of feeding options. By-product feeds are produced by a number of food processing industries, and such resources may impact traditional ruminant feeding practices by reducing the amount of concentrates fed to ruminants, providing feeding options when there is a scarcity of feed and reducing feed cost. Potato hash, a by-product from the production of potato snacks and chips, is available in large amounts in the Gauteng Province and is not widely used in livestock feeding. This by-product contains $150 \mathrm{~g}$ dry matter (DM)/kg of fresh potato hash, $700 \mathrm{~g}$ starch/kg DM, $11.16 \mathrm{MJ}$ metabolisable energy (ME)/kg DM, $105 \mathrm{~g}$ crude protein $(\mathrm{CP}) / \mathrm{kg} \mathrm{DM}, 370 \mathrm{~g}$ neutral detergent fibre (NDF)/kg DM and $163 \mathrm{~g}$ acid detergent fibre (ADF)/kg DM (Nkosi, 2009). If it is not consumed, it often gets mouldy and sour, and therefore unlikely to be used as an animal feed. Because of problems associated with the fresh form of potato hash, drying and ensiling are two options of preserving high moisture by-products. However, the drying process is costly and may not be affordable to the resourcepoor farmers.

Interest in conserving by-products by ensiling is steadily increasing, largely due to the increase in their use as animal feeds (Megias et al., 1998; Kayouli \& Lee, 1999; Bakshi et al., 2006; Kholif et al., 2007). Properly ensiled silage from high moisture by-products can replace costly feeds such as maize silage in ruminant diets (Itavo et al., 2000; Lallo et al., 2003; Pirmohammadi et al., 2006). However, ensiling of potato hash requires substantial amounts of fermentable sugars to produce sufficient lactic acid to reduce the pH and stabilize the product (McDonald, 1981; Wilkinson, 2005). Generally, potato by-products contain 
relatively low concentrations of water soluble carbohydrates (WSC) and lactic acid bacteria (LAB) (O`Kiely et al., 2002; Okine, 2007) the latter being killed off during the food processing of the potato (Moon, 1981). Thus, potato by-products require silage additives to improve the fermentation during ensiling. Some food byproducts have been ensiled successfully with chemical additives resulting in an improvement in fermentation quality and digestibility of the silage (Megias et al., 1998; Kholif et al., 2007).

However, chemical additives have their own limitations since they are corrosive to the equipment used and can be dangerous to handle. Consequently, biological additives are often preferred (Gwayumba, 1997). Biological additives have also their own limitations. They are costly to the farmer and their effectiveness can be less reliable, since it is based on the activity of living organisms (Weinberg \& Muck, 1996). Alternatively, food waste materials such as whey (Nkosi, 2003; Zobell et al., 2004; Bautista-Trujillo et al., 2009) and sugarcane molasses (Bolsen et al., 1996; Yunus et al., 2000; Van Niekerk et al., 2007; Nkosi et al., 2009) can be used as silage additives to ensile high moisture potato hash. The present study compared the fermentation characteristics of potato hash silage produced without or with additives (whey and molasses) with that of maize silage. This was followed by a study on the feed intake and performance of lambs consuming the silage diet and the digestibility of the diets.

\section{Materials and Methods}

Potato hash was collected from Simba (PTY) LTD (Andre Greyvensteyn Avenue, Isando, South Africa), a food producing factory in the Gauteng Province, and brought to the Agricultural Research Council -Irene Institute (longitude $28^{\circ} 13^{`} \mathrm{~S}$ : latitude $25^{\circ} 55^{\circ} \mathrm{E}$, altitude $1524 \mathrm{~m}$ ) South Africa for chemical analysis, silage making and the lamb feeding trial. To prevent effluent loss during ensiling, potato hash silage was prepared by mixing $800 \mathrm{~g}$ potato hash $/ \mathrm{kg}\left(850 \mathrm{~g} \mathrm{H}_{2} \mathrm{O} / \mathrm{kg}\right.$ and $/ \mathrm{kg} \mathrm{DM:} 105 \mathrm{~g} \mathrm{CP}, 43 \mathrm{~g}$ ash, $370 \mathrm{~g}$ aNDF, 163 g ADF and $110 \mathrm{~g}$ ether extract (EE)) with $200 \mathrm{~g} / \mathrm{kg}$ of Eragrostis curvula hay $\left(60 \mathrm{~g} \mathrm{H}_{2} \mathrm{O} / \mathrm{kg}\right.$ and $/ \mathrm{kg} \mathrm{DM}: 45$ $\mathrm{g} \mathrm{CP}, 39 \mathrm{~g}$ ash, $789 \mathrm{~g}$ aNDF, $432 \mathrm{~g} \mathrm{ADF}$ and $33 \mathrm{~g} \mathrm{EE}$ ). The silage-hay mixture was subjected to the following treatments: untreated control (no additive), or additives as whey or molasses added to the silage mixture. Where molasses was used, it was diluted with warm water at a ratio of $1: 2$ ( $4 \mathrm{~h}$ before application), and was sprayed over the material at a application rate of $30 \mathrm{~L}$ per ton fresh material (FM). Whey was screened for lactic acid bacteria (LAB) concentration, and contained a population of $6.95 \times 10^{5} \mathrm{LAB} \mathrm{cfu} / \mathrm{mL}$ ( \pm 0.341 s.e.m.) before ensiling. Whey was sprayed at $30 \mathrm{~L}$ per ton FM to obtain at least $>1.7 \times 10^{4} \mathrm{cfu} / \mathrm{g}$ FM. Maize silage, a fourth silage treatment was produced by chopping whole crop maize (Senkuil, Sensako, Brits, South Africa) (360 g H $\mathrm{H}_{2} \mathrm{O} / \mathrm{kg}$, a pH of 5.7 and $43 \mathrm{~g} \mathrm{WSC} / \mathrm{kg} \mathrm{DM}$ ) with a Feraboli 945 precision silage chopper (Fondata Nel, Cremona, Italy) to obtain a $5 \mathrm{~mm}$ chop length, and was ensiled in $210 \mathrm{~L}$ drums without an additive. In order to compensate, water that was added to the treated silage; both the maize and untreated potato hash were sprayed with $30 \mathrm{~L}$ of distilled water over a ton of FM to keep them at the same level of moisture as the treated silages. The materials were ensiled in $210 \mathrm{~L}$ drums, lined with plastic bags and closed with rubber lids to prevent damages to the bags by rodents. After $90 \mathrm{~d}$ of ensiling, the drums were opened and samples were collected and analysed for chemical composition and fermentation characteristics.

Experimental diets that contained either the potato hash silages or maize silage were formulated as shown in Table 1. The dietary treatments were: a) maize silage diet (MSd), b) untreated potato hash silage diet (UPHSd), c) whey treated potato hash silage diet (WPHSd) and d) molasses treated potato hash silage diet (MPHSd). Samples of the diets were collected fortnightly to determine the chemical composition. The diets were fed ad libitum to 32 South African Dorper lambs $(23.5 \pm 0.873 \mathrm{~kg}$ live weight) housed in individual metabolism crates $\left(2.2 \mathrm{~m}^{2}\right)$ in an insulated well-ventilated barn. The lambs were allocated in a randomized complete block design on the basis of live weight to the four diets, resulting in eight lambs per treatment. Lambs were ear tagged, and treated against internal and external parasites before the commencement of the trial. Feed intake was measured daily while live weight was measured at the start of the trial and at weekly intervals until the end of the trial. A 14 day dietary adaptation period was offered and the trial lasted for 63 days. All animals were treated according to the regulations of the Animal Ethics Committee of the ARC-API (2008).

A seven-day faecal collection period was conducted a week after the growth study. Lambs were fitted with leather harnesses and canvass bags attached to the back of each lamb three days before the collection period started. Daily feed intake was recorded and faeces were collected. Faeces accumulated for the seven 
day period were pooled per lamb and sub-samples were collected for laboratory analyses. Faeces samples were frozen at $-20^{\circ} \mathrm{C}$.

A $40 \mathrm{~g}$ silage sample from each drum was collected and mixed with $360 \mathrm{~mL}$ of distilled water in a stomacher bag, homogenized and left at $10{ }^{\circ} \mathrm{C}$ for $24 \mathrm{~h}$ (Suzuki \& Lund, 1980). It was then homogenized for $4 \mathrm{~min}$ and filtered through Whatman No. 4 filter paper (G.I.C. Scientific, Midrand, South Africa). The extract was used for determination of $\mathrm{pH}$, WSC, volatile fatty acids (VFAs), lactic acid (LA) and ammonia-N $\left(\mathrm{NH}_{3}-\mathrm{N}\right)$. The WSC were determined by the phenol-sulphuric acid method according to Dubois et al. (1956) and lactic acid, using the colorimetric method of Barker \& Summerson (1941) as modified by Pryce (1969). The VFA concentrations were determined with a Varian 3300 FID Detector gas chromatograph (Varian Associates, Inc., Palo Alto, CA, USA) by the procedure of Suzuki \& Lund (1980). Ammonia-N was determined by distillation using a Buchi 342 apparatus and a Metrohm 655 Dosimat with an E526 titrator according to AOAC (1990). This method is based on the method of Pearson \& Muslemuddin (1968) for determining volatile nitrogen.

The DM of silage and the diets was determined by drying the samples at $60{ }^{\circ} \mathrm{C}$ in a forced air oven until a constant mass was achieved (AOAC, 1990). After drying, the samples were ground through a $1 \mathrm{~mm}$ screen (Wiley mill, Standard Model 3, Arthur H. Thomas Co., Philadelphia, PA) for chemical analyses. Following the procedures of Van Soest et al. (1991), the aNDF concentration was determined using amylase (Sigma-Aldrich Co. LTD., Gillingham, UK, no. A-1278) and 2-ethoxyethanol, and the ADF concentration was determined using the Fibretec System equipment (Tecator LTD., Thornbury, Bristol, UK). Residual ash content was taken into account for both aNDF and ADF results. Crude protein, ash and EE were determined according to the procedure of AOAC (1990), while ME was determined, using the gas production technique of Pienaar (1994).

Data for the fermentation and chemical composition of the silage and diets was subjected to ANOVA for randomized complete design, while that of growth and digestibility studies were subjected to a randomized complete block design using Genstat (2000). Where F value was significant $(\mathrm{P}<0.05)$, statistical differences between means were declared using the Fisher's protected least significance difference (LSD).

Table 1 Composition of experimental diets (\%, as is basis)

\begin{tabular}{lcccc}
\hline \multirow{2}{*}{ Ingredient \% } & \multicolumn{4}{c}{ Treatments } \\
\cline { 2 - 5 } & UPHSd & MPHSd & WPHSd & MSd \\
\hline Maize meal & 52 & 54 & 51 & 44 \\
Wheat bran & 10 & 10 & 10 & 10 \\
Molasses meal & 10 & 10 & 10 & 10 \\
Silage & 20 & 18 & 19 & 8 \\
Hay (E. curvula) & 0 & 0 & 0 & 5 \\
Cotton oil cake & 5 & 5 & 7 & 1 \\
Feed lime & 1.4 & 1.4 & 1.4 & 0.5 \\
Ammonium sulphate & 0.5 & 0.5 & 0.5 & 0.5 \\
Urea & 0.6 & 0.5 & 0.4 & 0.4 \\
Salt & 0.4 & 0.4 & 0.1 & 0.1 \\
Min-vit. premix & 0.1 & 0.1 & & \\
\hline
\end{tabular}

UPHSd - untreated potato hash silage diet; MPHSd - molasses potato hash silage diet; WPHSd - whey potato hash silage diet; MSd - maize silage diet.

${ }^{a} 1 \mathrm{~kg}$ mineral-vitamin premix contained: $7.5 \mathrm{mg}$ selenium; $15 \mathrm{~g}$ magnesium; $90 \mathrm{~g}$ sodium; $6 \mathrm{~g}$ zinc; $5.5 \mathrm{~g}$ manganese; $20 \mathrm{mg}$ copper; $20 \mathrm{mg}$ iodine; $189 \mathrm{~g}$ calcium; 50 g phosphorus; 6000000 I.U. vitamin A; 60000 I.U. vitamin D3; 500 $\mathrm{mg}$ vitamin $\mathrm{E} ; 50 \mathrm{mg}$ vitamin $\mathrm{B} 1$.

\section{Results and Discussion}

Data on the chemical composition and fermentation characteristics of the silages are presented in Table 2. After 90 days of ensiling, the DM of MS was higher $(\mathrm{P}<0.05)$ than that of the potato hash silages 
due to low DM content $(250 \mathrm{~g} / \mathrm{kg})$ of the latter at pre-ensiling. Water-soluble carbohydrates are regarded as essential substrates for the growth of LAB for proper fermentation, and low levels may restrict LAB growth (McDonald et al., 1991). Haigh \& Parker (1985) suggested that a concentration of $30 \mathrm{~g} \mathrm{WSC} / \mathrm{kg}$ DM in a herbage is critical for successful fermentation. The concentration of WSC in the potato hash mixture at preensiling was $22 \mathrm{~g} / \mathrm{kg} \mathrm{DM}$, indicating that it was not enough for efficient fermentation. Although potato hash contains high levels of starch, starches are only sparingly soluble in water and lactic acid bacteria do not have the ability to ferment starch (McDonald et al., 1991). This justified the addition of whey and molasses to improve the fermentation process.

The $\mathrm{pH}$ of potato hash silages after 90 days of ensiling was reduced to 4.5 for the UPHS and 4.2 for the MPHS and WPHS. However, the pH of UPHS was not low enough for efficient preservation. Weissbach (1968) stated that for efficient preservation of material with DM contents of 200 and $250 \mathrm{~g} / \mathrm{kg}$, a pH of 4.20 and 4.35, respectively, are required. According to McDonald et al. (2002) silage with a pH range of 3.8 to 4.2 is considered well preserved and the UPHS did not reach this target. Moreover, good quality silage is characterized by a lactic acid concentration of $30-140 \mathrm{~g} / \mathrm{kg}$ (Zobell et al., 2004) and the UPHS silage had a lactic acid concentration $(26 \mathrm{~g} / \mathrm{kg} \mathrm{DM})$ lower than this level. Maize silage had the lowest $(\mathrm{P}<0.05) \mathrm{pH}$, acetic acid, butyric acid, propionic acid and $\mathrm{NH}_{3}-\mathrm{N}$, and higher lactic acid $(\mathrm{P}<0.05)$ concentrations compared to the potato hash silages. It has been reported that silage from maize can be produced without the use of additives due to the fact that maize has a low buffering capacity and enough sugar for efficient fermentation (McDonald, 1981; Meeske, 2005). This might be the reasons for its better fermentation quality compared to the potato hash silages.

Table 2 Chemical composition and fermentation characteristics of pre-ensiled potato hash, potato hash silage and maize silage after 90 days of ensiling $(n=7)$

\begin{tabular}{|c|c|c|c|c|c|c|}
\hline & \multirow{2}{*}{$\begin{array}{l}\text { Pre-ensiled } \\
\text { potato hash } \\
\text { mixture }\end{array}$} & \multicolumn{4}{|c|}{ Ensiled treatments } & \multirow{2}{*}{ s.e.m. } \\
\hline & & UPHS & MPHS & WPHS & MS & \\
\hline $\mathrm{DM}, \mathrm{g} / \mathrm{kg}$ & 250 & $232^{\mathrm{b}}$ & $236^{\mathrm{b}}$ & $230^{c}$ & $320^{\mathrm{a}}$ & 0.530 \\
\hline Ash, g/kg DM & 59.4 & $60.4^{\mathrm{a}}$ & $55.0^{\mathrm{b}}$ & $61.1^{\mathrm{a}}$ & $53.7^{\mathrm{c}}$ & 1.81 \\
\hline $\mathrm{CP}, \mathrm{g} / \mathrm{kg} \mathrm{DM}$ & 89.1 & $72.3^{\mathrm{c}}$ & $82.5^{\mathrm{b}}$ & $86.0^{\mathrm{a}}$ & $86.0^{\mathrm{a}}$ & 0.003 \\
\hline $\mathrm{CF}, \mathrm{g} / \mathrm{kg} \mathrm{DM}$ & 259 & $334^{\mathrm{b}}$ & $303^{c}$ & $275^{\mathrm{d}}$ & $340^{\mathrm{a}}$ & 0.4 \\
\hline EE, g/kg DM & 73 & $45^{\mathrm{a}}$ & $37^{\mathrm{b}}$ & $34^{\mathrm{c}}$ & $23^{\mathrm{d}}$ & 0.283 \\
\hline ME, MJ/kg DM & 10.0 & $7.8^{\mathrm{c}}$ & $9.6^{\mathrm{b}}$ & $9.7^{\mathrm{b}}$ & $11.8^{\mathrm{a}}$ & 0.05 \\
\hline $\mathrm{pH}$ & 4.8 & $4.5^{\mathrm{a}}$ & $4.2^{\mathrm{b}}$ & $4.2^{\mathrm{b}}$ & $3.9^{\mathrm{c}}$ & 0.01 \\
\hline WSC, $\mathrm{g} / \mathrm{kg}$ DM & 22 & $13^{\mathrm{c}}$ & $17^{\mathrm{b}}$ & $15^{\mathrm{bc}}$ & $36^{\mathrm{a}}$ & 0.27 \\
\hline $\mathrm{LA}, \mathrm{g} / \mathrm{kg} \mathrm{DM}$ & & $26.1^{\mathrm{d}}$ & $47.5^{\mathrm{b}}$ & $42.5^{\mathrm{c}}$ & $77.6^{\mathrm{a}}$ & 0.18 \\
\hline $\mathrm{AA}, \mathrm{g} / \mathrm{kg} \mathrm{DM}$ & & $28.5^{\mathrm{a}}$ & $21.0^{c}$ & $23.5^{\mathrm{b}}$ & $3.7^{\mathrm{d}}$ & 0.26 \\
\hline PA, g/kg DM & & $6.3^{\mathrm{a}}$ & $6.7^{\mathrm{a}}$ & $5.2^{\mathrm{b}}$ & $0.1^{\mathrm{c}}$ & 0.88 \\
\hline $\mathrm{BA}, \mathrm{g} / \mathrm{kg} \mathrm{DM}$ & & $0.91^{\mathrm{a}}$ & $0.42^{\mathrm{c}}$ & $0.52^{\mathrm{b}}$ & $0.01^{\mathrm{d}}$ & 0.03 \\
\hline $\mathrm{NH}_{3}-\mathrm{N}$ as $\% \mathrm{TN}$ & & $9.8^{\mathrm{a}}$ & $7.5^{\mathrm{b}}$ & $7.5^{\mathrm{b}}$ & $5.1^{c}$ & 0.09 \\
\hline
\end{tabular}

$\overline{\mathrm{a}, \mathrm{b}, \mathrm{c}}$ Means with different superscripts in a row differ significantly $(\mathrm{P}<0.05)$.

UPHS - untreated potato hash silage; MPHS - molasses potato hash silage; WPHS - whey potato hash silage; MS maize silage; DM - dry matter; $\mathrm{CP}$ - crude protein; $\mathrm{CF}$ - crude fibre; EE - ether extract; $\mathrm{ME}$ - metabolisable energy; LA - lactic acid; WSC - water-soluble carbohydrates; AA - acetic acid; PA - propionic acid; BA - butyric acid; $\mathrm{TN}$ - total nitrogen.

The fermentation characteristics of MS recorded in the present study correspond well with that of maize silage with a DM content of 300 to $400 \mathrm{~g} / \mathrm{kg}$, reported by Kung \& Shaver (2001). This study further revealed that the addition of whey and molasses increased $(\mathrm{P}<0.05)$ the concentration of lactic acid, reduced silage $\mathrm{pH}$ and the concentrations of butyric acid and $\mathrm{NH}_{3}-\mathrm{N}$ compared to the UPHS, indicative of wellpreserved silages (McDonald et al., 1991). This result agrees well with previous work that reported higher lactic acid concentrations, lower $\mathrm{pH}$ and $\mathrm{NH}_{3}-\mathrm{N}$ concentration when molasses (Bolsen et al., 1996; Yunus et 
al., 2000) and whey (Zobell et al., 2004; Bautista-Trujillo et al., 2009,) were added to a forage at ensiling compared to the control. Moreover, whey and molasses addition reduced $(\mathrm{P}<0.05)$ the fibre content of the silage as compared to MS and UPHS. This could be attributed to partial hydrolysis of hemicelluloses in the treated silages (Muck \& Kung, 1997). Our result agrees with Fazaeli et al. (2003) and Guney et al. (2007) who reported a decrease in fibre content of liquid whey treated straw silage and for molasses treated sorghum silage, respectively.

Ammonia- $\mathrm{N}$ in silage reflects the degree of protein degradation (Wilkinson, 2005), and well-preserved silages contain less than $100 \mathrm{~g} \mathrm{NH}_{3}-\mathrm{N} / \mathrm{kg}$ total nitrogen (TN) (McDonald et al., 2002). The silages in the present study had $\mathrm{NH}_{3}-\mathrm{N}$ concentrations of less than $100 \mathrm{~g} \mathrm{NH}_{3}-\mathrm{N} / \mathrm{kg} \mathrm{TN}$. However, treating potato hash silage at ensiling with either whey or molasses further reduced $(\mathrm{P}<0.05)$ the $\mathrm{NH}_{3}-\mathrm{N}$ concentration compared to the UPHS, confirming the work of other researchers (Yunus et al., 2000; Bautista-Trujillo et al., 2009; Nkosi et al., 2009) who found reduced $\mathrm{NH}_{3}-\mathrm{N}$ production. This could be explained by the fact that whey and molasses reduced the $\mathrm{pH}$, resulting in a decreased production of $\mathrm{NH}_{3}-\mathrm{N}$ in the silage compared to the UPHS. The higher concentration of $\mathrm{NH}_{3}-\mathrm{N}$ in UPHS led to a decrease in the $\mathrm{CP}$ content of the silage compared to the other silages.

A higher $(\mathrm{P}<0.05)$ concentration of butyric acid occurred in the UPHS, leading to a reduced energy content of the silage compared to the other silages. It is well established that adding molasses and whey reduced the concentration of butyric acid in silage (Bautista-Trujillo et al., 2009; Nkosi et al., 2009). A concentration of $<0.1 \mathrm{~g}$ butyric acid/ $\mathrm{kg} \mathrm{DM}$ is typically found in well-preserved silage (Kung \& Shaver, 2001) and only the MS had the acceptable butyric acid concentration compared to the potato hash silage. Butyric acid is associated with a clostridial type of fermentation and is usually associated with high moisture silages (McDonald, 1981), and MS had a higher DM content compared to the potato hash silages. The ME content in the MPHS, WPHS and MS were within the range of 9.6-12.2 MJ ME/kg DM, typically reported for silages (Wilkinson, 2005). The reduction of ME in the UPHS might be attributed to the high butyric acid content, which is an indication of the loss of energy in the silage (McDonald, 1981).

Table 3 Chemical composition of experimental diets formulated with either potato hash silages or maize silage and fed to lambs $(\mathrm{n}=7)$

\begin{tabular}{|c|c|c|c|c|c|}
\hline & \multicolumn{4}{|c|}{ Treatments } & \multirow{2}{*}{ s.e.m } \\
\hline & UPHSd & MPHSd & WPHSd & MSd & \\
\hline $\mathrm{DM} / \mathrm{kg}$ & $774^{\mathrm{b}}$ & $781^{\mathrm{a}}$ & $775^{\mathrm{b}}$ & $784^{\mathrm{a}}$ & 0.53 \\
\hline Ash g/kg DM & $73.8^{\mathrm{a}}$ & $68.2^{\mathrm{b}}$ & $67.6^{\mathrm{b}}$ & $63.4^{\mathrm{c}}$ & 1.59 \\
\hline $\mathrm{CP}$ g/kg DM & $134^{\mathrm{b}}$ & $141^{\mathrm{a}}$ & $137^{\mathrm{ab}}$ & $141^{\mathrm{a}}$ & 1.03 \\
\hline $\mathrm{ME} \mathrm{MJ/kg} \mathrm{DM}$ & 11.8 & 11.9 & 11.8 & 12.0 & 0.69 \\
\hline $\mathrm{ADF} \mathrm{g} / \mathrm{kg} \mathrm{DM}$ & $132^{\mathrm{b}}$ & $89^{\mathrm{d}}$ & $103^{\mathrm{c}}$ & $181^{\mathrm{a}}$ & 0.37 \\
\hline aNDF $\mathrm{g} / \mathrm{kg}$ DM & $309^{\mathrm{b}}$ & $222^{\mathrm{d}}$ & $253^{\mathrm{c}}$ & $348^{\mathrm{a}}$ & 1.17 \\
\hline EE g/kg DM & $45.1^{\mathrm{a}}$ & $35.3^{\mathrm{c}}$ & $37.6^{\mathrm{b}}$ & $35.8^{\mathrm{bc}}$ & 0.57 \\
\hline IVOMD \% & $71^{\mathrm{d}}$ & $76^{\mathrm{b}}$ & $75^{\mathrm{c}}$ & $77^{\mathrm{a}}$ & 0.02 \\
\hline
\end{tabular}

${ }^{a, b, c,}$ Means with different letters in a row differ significantly $(\mathrm{P}<0.05)$.

UPHSd - untreated potato hash silage diet; MPHSd - molasses potato hash silage diet; WPHSd - whey potato hash silage diet; MSd - maize silage diet; CP - crude protein; ME - metabolisable energy; ADF - acid detergent fibre; aNDF - neutral detergent fibre (amylase technique); EE - ether extract; IVOMD - in vitro organic matter digestibility.

According to Wilkinson (2005) silages should contain 72 - 89 g CP/kg DM (McDonald, 1981) and 9.6 - 12.2 MJ ME/kg DM and would require supplementation to achieve a daily gain of more than $150 \mathrm{~g} / \mathrm{d}$ in commercial lamb operations (Marley et al., 2007). Feeding lambs on silage alone generally leads to either loss of live weight or limited daily gains (Fitzgerald, 1986). Speijers et al. (2005) obtained daily gains of 45 $\mathrm{g} / \mathrm{d}$ from lambs that were fed lucerne silage supplemented with $250 \mathrm{~g}$ sugarbeet pellets. Data on the chemical composition of the silages (Table 2) showed that they were low in DM, CP and energy content. Therefore diets that contained $<200 \mathrm{~g} / \mathrm{kg}$ silage (either potato hash or maize silages) were formulated (Table 1) to 
improve the nutritive value of the silage diets. The chemical composition of the diets (Table 3 ) shows that the diets had similar $(\mathrm{P}>0.05)$ energy levels, but had a different $(\mathrm{P}<0.05)$ content of $\mathrm{DM}, \mathrm{CP}$, fibre, EE and in vitro organic matter digestibility (IVOMD). The maize silage diet contained higher $(\mathrm{P}<0.05)$ concentrations of the fibre fractions while the fibre fractions for WPHSd and MPHSd were lower.

Data on the growth performance and nutrient digestibility in lambs fed the experimental diets are shown in Table 4. Lambs fed the MS and MPHS diets had higher $(\mathrm{P}<0.05)$ dry matter intake (DMI), ADG and final live weights compared to those in the other diets. This might be attributed to a higher DM and CP content in the two silages which are known to improve DMI and growth rates in ruminants (Mustafa et al., 2008). Moreover, feeding sheep on maize silage is known to result in a positive associative effect on feed intake (Provenza, 1995). It has been reported that finishing lambs on a diet that contained $180 \mathrm{~g}$ apple pomace silage/kg depressed DMI compared to a dried apple pomace diet (Karami et al., 1996). In contrast, Jetana et al. (2009) did not report a depressed DMI when a diet containing $200 \mathrm{~g}$ pineapple wastes silage $/ \mathrm{kg}$ was fed to buffaloes. The present study recorded DMI of 1056, 1099, 1188 and $1250 \mathrm{~g} / \mathrm{d}$ for the UPHS, WPHS, MPHS and the MS diets, respectively. Taasoli \& Kafilzadeh (2008) recorded DMI of $938 \mathrm{~g} / \mathrm{d}$ in lambs fed a diet that contained $300 \mathrm{~g}$ apple pomace silage/kg, which is lower than those of the present study.

The present study recorded daily gains of 192, 205, 218 and $250 \mathrm{~g} / \mathrm{d}$ for UPHSd, WPHSd, MSd and MPHSd, respectively. Rams fed on a halophytic silage without supplementation recorded gains of $162 \mathrm{~g} / \mathrm{d}$ (Abdul-Aziz et al., 2001) which is lower than those of the present study. However, the work of Taasoli \& Kafilzadeh (2008) reported daily gains of $199.8 \mathrm{~g} / \mathrm{d}$, comparable to those of the present study. Meeske \& Basson (1998) recorded daily gains of $255 \mathrm{~g} / \mathrm{d}$ in lambs fed a ration that contained $600 \mathrm{~g}$ maize silage $/ \mathrm{kg} \mathrm{DM}$ of diet, which is comparable to the MSd of the present study. However, Bosman et al. (2000) obtained a growth rate of $154 \mathrm{~g} / \mathrm{d}$ in lambs fed a diet that contained $700 \mathrm{~g} / \mathrm{kg}$ maize silage which is lower than that of MS diet in the present study. Higher $(\mathrm{P}<0.05)$ final weights were obtained in the MSd and MPHSd.

Table 4 Mean dry matter intake (DMI), performance and digestibility coefficients of experimental silage diets fed to lambs $(\mathrm{n}=8)$

\begin{tabular}{|c|c|c|c|c|c|}
\hline & \multicolumn{4}{|c|}{ Treatments } & \multirow{2}{*}{ s.e.m. } \\
\hline & UPHd & MPHd & WPHd & $\mathrm{MSd}$ & \\
\hline DMI $g / d$ & $1099^{\mathrm{b}}$ & $1188^{\mathrm{a}}$ & $1056^{\mathrm{b}}$ & $1250^{\mathrm{a}}$ & 68.3 \\
\hline ADG $\mathrm{g} / \mathrm{d}$ & $192^{\mathrm{d}}$ & $250^{\mathrm{a}}$ & $205^{\mathrm{c}}$ & $218^{\mathrm{b}}$ & 0.2 \\
\hline FCR $\mathrm{kg} / \mathrm{kg}$ & $5.7^{\mathrm{a}}$ & $4.8^{\mathrm{c}}$ & $5.2^{\mathrm{b}}$ & $5.7^{\mathrm{a}}$ & 0.19 \\
\hline IBW kg & 23.8 & 23.2 & 23.7 & 23.3 & 0.87 \\
\hline FBW kg & $35.9^{\mathrm{b}}$ & $38.8^{\mathrm{a}}$ & $36.7^{\mathrm{b}}$ & $39.6^{\mathrm{a}}$ & 1.88 \\
\hline \multicolumn{6}{|c|}{ Digestibility coefficient (\%) } \\
\hline DMD & $62.8^{\mathrm{b}}$ & $72.5^{\mathrm{a}}$ & $70.2^{\mathrm{a}}$ & $71.2^{\mathrm{a}}$ & 3.76 \\
\hline OMD & $65.2^{\mathrm{b}}$ & $73.9^{\mathrm{a}}$ & $71.0^{\mathrm{a}}$ & $74.2^{\mathrm{a}}$ & 3.81 \\
\hline CPD & $53.2^{\mathrm{b}}$ & $64.1^{\mathrm{a}}$ & $53.5^{\mathrm{b}}$ & $64^{\mathrm{a}}$ & 1.97 \\
\hline EED & $58.7^{\mathrm{a}}$ & $56.6^{\mathrm{b}}$ & $52.0^{\mathrm{b}}$ & $55.6^{\mathrm{b}}$ & 1.02 \\
\hline ADFD & $45.7^{\mathrm{b}}$ & $43.6^{\mathrm{c}}$ & $42.5^{\mathrm{c}}$ & $54.8^{\mathrm{a}}$ & 1.40 \\
\hline aNDFD & $67.6^{\mathrm{b}}$ & $66.2^{\mathrm{b}}$ & $68.8^{\mathrm{b}}$ & $74.8^{\mathrm{a}}$ & 2.74 \\
\hline
\end{tabular}

${ }^{a, b, c}$ Means with different superscripts in a row differ significantly $(\mathrm{P}<0.05)$.

UPHSd - untreated potato hash silage die; MPHSd - molasses potato hash silage diet; WPHSd - whey potato hash silage diet; MSd - maize silage diet; s.e.m - standard error of means; ADG - average daily gains; FCR - feed conversion ratio; IBW - initial body weight; FBW - final body weight.

DMD - dry matter digestibility; OMD - organic matter digestibility; CPD - crude protein digestibility; EED - ether extract digestibility; ADFD - acid detergent fibre digestibility; NDF - neutral detergent fibre digestibility.

Lambs with higher feed conversion rates (FCR) require longer finishing periods and a FCR of $<5$ indicates a relatively good feeding management with the diet (Bosman et al., 2000). Better $(\mathrm{P}<0.05)$ FCR was obtained with MPHSd and WPHS (4.8 and 5.2) compared to 5.7 from the other diets. Dietary addition of 
$300 \mathrm{~g}$ apple pomace silage/kg resulted in a FCR of 4.69 in lambs (Taasoli \& Kafilzadeh, 2008) comparable to the MPHSd in the present study. Higher FCR $(9-12)$ were recorded in Omani lambs fed ration that contained 60\% forage (Mahgoub et al., 2000). Other workers reported lower values (5.7 to 4.1) but these were obtained with rations of higher concentrate inclusion rates (Pineda et al., 1998; Archimede et al., 2007) which are in agreement with the results of the present study.

The digestibility of DM and OM was similar $(\mathrm{P}>0.05)$ for the MS, MPHS and WPHS diets, but higher $(\mathrm{P}<0.05)$ than that of UPHSd. The MS and MPHS diets had higher $(\mathrm{P}<0.05)$ digestibility of CP compared to the other diets which led to improved growth performance in lambs compared to those fed on other diets. In addition, MS diet had the higher $(\mathrm{P}<0.05)$ IVOMD and digestibility of ADF and aNDF compared to the other diets.

\section{Conclusions}

It can be concluded that whey and molasses addition improved the fermentation characteristics of potato hash silage. Improved lamb performance was obtained with MPHSd followed by MSd, suggesting that MPHSd can replace MSd in lamb diet at 20\% dietary inclusion level without any adverse effect on animal performance. Furthermore, molasses addition to potato hash at ensiling improved its acceptability and nutrient digestibility in lambs compared to the control.

\section{References}

Abdul-Aziz, G.M., El Shaer, R.M., Fahmy, A.A., Shalaby, A.S. \& Abd El Gawad, A.M., 2001. Carcass quality of fattened sheep fed halophytic silage with non-conventional energy supplements in Egypt. In: Production Systems and Product Quality in Sheep and Goats. Eds Rubino, R. \& Morand-Fehr, P., Options Mediterraneennes: Serie A. Seminaires Mediterraneens, 46. 35-39.

AOAC, 1990. Official Methods of Analysis. $15^{\text {th }}$ ed. Association of Official Analytical Chemists, Washington, D.C., USA.

Archimede, H., Pellonde, P., Despois, P., Etienne, T. \& Alexandre, G., 2007. Growth and carcass traits of Ovin Martinik lambs fed various ratios of tropical forage to concentrate under intensive conditions. Small Rumin. Res. 75, 162-170.

Bakshi, M.P.S., Wadhwa, M., Kaushal, S. \& Ameir, A., 2006. Nutritional value of ensiled fruit and vegetable wastes. In: Improving animal productivity by supplementary feeding of multinutrient blocks, controlling internal parasites and enhancing utilization of alternate feed resources. Part II: Efficient utilization of alternate feed resources. Eds Makkar, H.P.S. \& Smith, T., International Atomic Energy Agency (IAEA), Vienna, Austria. pp. 191-196.

Barker, S.B. \& Summerson, W.H., 1941. The colorimetric determination of lactic acid in biological material. J. Biol. Chem. 138, 535 - 554.

Bautista-Trujillo, G.U., Cobos, M.A., Ventura-Canseco, L.M.C, Ayora-Talavera, T., Abud-Archila, M., Olivia-Llaven, M.A., Dendooven, L. \& Gutierrez-Miceli, F.A., 2009. Effect of sugarcane molasses and whey on silage quality of maize. Asian J. Crop Sci. 1 (1), 34-39.

Bolsen, K.K., Ashbell, G. \& Weinberg, Z., 1996. Silage fermentation and silage additives: Review. AsianAustral. J. Anim. Sci. 9, 483-494.

Bosman, M.J.C., Webb, E.C., Cilliers, H.J. \& Steyn, H.S., 2000. Growth, carcass and sensory characteristics of $m$. longissimus lumborum from wethers fed silage diets made from maize or various sorghum varieties. S. Afr. J. Anim. Sci. 30, 36-42.

Dubois, M., Giles, K.A., Hamilton, J.K., Rebes, P.A. \& Smith, F., 1956. Colorimetric method for determination of sugars and related substances. Anal. Chem. 28, 350-356.

Fazaeli, H., Tokasi, M.V. \& Arjmand, S., 2003. Effect of urea - whey treatment on the chemical composition and digestibility of wheat straw. Proc. Br. Soc. Anim. Sci. pp. 165.

Fitzgerald, J.J., 1986. Finishing of store lambs on silage based diets. 3. Effects of formic acid with and without formaldehyde as silage additives and barley supplementation on silage intake and lamb performance. Irish J. Agric. Res. 25, 363-377.

Gads, 2006. The Gauteng Agricultural Development Strategy, December, 2006. Department of Agriculture, Conservation and Environment. Johannesburg, South Africa.

Genstat for Windows ${ }^{\circledR} 2000$. Release 4.2. $5^{\text {th }}$ Edition. VSN International Ltd., Oxford, UK. 
Guney, M., Demirel, M., Celik, S., Yunus, B. \& Taner, L., 2007. Effects of urea, molasses and urea plus molasses supplementation to sorghum silage on the silage quality, in vitro organic matter digestibility and metabolic energy contents. J. Biol. Sci. 7, 401-404.

Gwayumba, W., 1997. Lactic acid bacterial inoculants and fibrolytic enzymes in forage preservation and degradability. PhD dissertation, University of Saskatchewan, Saskatoon, Canada.

Haigh, P.M. \& Parker, J.V.G., 1985. Effect of silage additives and wilting on silage fermentation, digestibility and intake, and on live weight change of young cattle. Grass Forage Sci. 40, 429-436.

Itavo, L.C.V., dos Santos, G.T., Jobim, C.C., Voltolini, T.V. \& Ferreira, C.C.B., 2000. Replacement of corn silage by orange peel silage in the feeding of dairy cows, intake, milk production and composition. Rev. Bras. Zootec. 29 (5), 1498-1503.

Jetana, T., Suthikrai, W., Usawang, S., Vongpipatana, C., Sophon, S. \& Liang, J.B., 2009. The effects of concentrate added to pineapple (Ananas Comosus linn. Mer.) waste silage in differing ratios to form complete diets, on digestion, excretion of urinary purine derivatives and blood metabolites in growing male Thai swamp buffaloes. Trop. Anim. Health Prod. 41, 449-459.

Karami, M., G.H. Ghorbani, G.H. \& H. Fazaeli, H., 1996. Replacement of alfalfa by ensiled apple pomace in the ration of Bahktiari male lambs. Proc. 1st Animal Nutrition Congress in Iran. Anim. Sci. Res. Inst. Karaj, Iran (cited by Taasoli \& Kafilzadeh, 2008).

Kayouli, C. \& Lee, S., 1999. Silage from by-products for smallholders. In: Silage making in the tropics with particular emphasis on smallholders. Ed. 't Mannetje, L., FAO Plant Production \& Protection Paper 161. pp. 85-95.

Khattab, H.M., Kholif, A.M., El-Alamy, H.A., Salem, F.A. \& El-Shewy, A.A., 2000. Ensiled banana wastes with molasses or whey for lactating buffaloes during early lactation. Asian-Austral. J. Anim. Sci. 13, 619-624.

Kholif, S.M., Abo-El-Nor, S.A.H. \& Khorshed, M.M., 2007. Effect of adding some chemical agents to ensiled vegetable and fruit market wastes on silage quality and the performance of lactating goats. Int. J. Dairy Sci. 2 (4), 312-320.

Kung Jr., L. \& Shaver, R., 2001. Interpretation and use of silage fermentation analysis reports. University of Wisconsin, Madison, WI, USA. Focus on Forage 3(13), 1-5.

Lallo, F.H., do Prado, I.N., do Nascimento, W.G., Zeoula, L.M., Moreira, F.B. \& Wada, F.Y., 2003. Substitution levels of corn silage by pineapple by-products on ruminal degradability in beef cattle. Rev. Bras. Zootec., 32 (3), 719-726.

Mahgoub, O., Lu, C.D. \& Early, I.R.J., 2000. Effects of dietary energy density on feed intake, body weight gain and carcass chemical composition of Omani growing lambs. Small Rumin. Res. 37, 35-42.

Marley, C.L., Fychan, R., Fraser, M.D., Sanderson, R. \& Jones, R., 2007. Effects of feeding different ensiled forages on the productivity and nutrient-use efficiency of finishing lambs. Grass For. Sci. 62, 1-12.

McDonald, P., 1981. The Biochemistry of Silage. John Wiley \& Sons. Chichester, New York, N.Y., USA.

McDonald, P., Henderson, A.R. \& Heron, S.J.E., 1991. The Biochemistry of Silage. Chalcombe Publications, Marlow, Buckinghamshire, UK. pp. 109.

McDonald, P., Edwards, R.A., Greenhalgh, J.F.D. \& Morgan, C.A., 2002. Animal Nutrition. 6th ed. Longman Scientific and Technical, Prentice Hall, New Jersey, USA.

Meeske, R., 2005. Silage additives: Do they make a difference? S. Afr. J. Anim. Sci. 6, 49-55.

Meeske, R. \& Basson, H.M., 1998. The effect of lactic acid bacterial inoculant on maize silage. Anim. Feed Sci. Technol. 70, 239-247.

Megias, M.D., Hernandez, F., Cano, J-A., Martinez-Terual, A. \& Gallego, J.A., 1998. Effects of different additives on the cell wall and mineral fractions of artichoke (Cynara scolymus) and orange (Citrus aurantium L) by-product silage. J. Sci. Food Agric. 76, 173-178.

Moon, N.J., 1981. Effect of inoculation of vegetable processing wastes with Lactobacillus plantarum on silage fermentation. J. Sci. Food Agric. 32, 675-683.

Muck, R.E. \& Kung Jr., L., 1997. Effects of silage additives on ensiling. In: Silage: Field to Feedbunk. NRAES-99, Ithaca, NY. pp. 187-199.

Mustafa, M.I., Chadwick, J.P., Akhtar, P., Ali, S., LaTeef, M. \& Sultan, J.I., 2008. The effect of concentrate and silage based finishing diets on the growth performance and carcass characteristics of Suffolk cross and Scottish Blackface lambs. Turk. J. Vet. Anim. Sci. 32 (3), 191-197. 
Nkosi, B.D., 2003. Silage making from mango and citrus leaves for the resource poor emerging farmer in South Africa. MSA dissertation, Centre for Sustainable Agriculture, University of the Free State, South Africa.

Nkosi, B.D., 2009. Potato hash silage as an alternative feed source for livestock farmers in the Gauteng Province. $\mathrm{PhD}$ Dissertation (Unpublished). Centre for Sustainable Agriculture and Rural Development. University of the Free State, Bloemfontein, South Africa.

Nkosi, B.D., Meeske, R., Palic, D. \& Langa, T., 2009. Laboratory evaluation of an inoculant for ensiling whole crop maize in South Africa. Anim. Feed Sci. Technol. 150, 144-149.

O'Kiely, P., Moloney, A. \& O'Roirdan, E.D., 2002. Co-ensiling of potatoes with unwilted or wilted grass. In: Reducing the cost of beef production by increasing silage intake: Beef Production series, 51. pp. 63-64.

Okine, A.R.A., 2007. Improving the preservation quality of high moisture by-product feedstuffs by ensilage and use of additives. PhD Dissertation, Iwate University, Japan.

Pienaar, J.P., 1994. Theoretical and applied aspects of voluntary feed intake by ruminants, with special reference to the kinetics of rumen digestion. PhD dissertation, University of Natal, Pietermaritzburg, South Africa.

Pearson, D. \& Muslemuddin, M., 1968. The accurate determination of volatile nitrogen in meat and fish. J. Assoc. Publ. Anal. 6, 117-123.

Pineda, J., Palma, J.M, Haenlein, G.F.W. \& Galina, M.A., 1998. Fattening of Pelibuey hair sheep and crossbreds (Rambouillet-Dorset x Pelibuey) in the Mexican tropics. Small Rumin. Res. 27, 263-266.

Pirmohammadi, R., Rouzbehan, Y., Reza Yazdi, K. \& Zahedif Ar,M., 2006. Chemical composition, digestibility and in situ degradability of dried and ensiled apple pomace and maize silage. Small Rumin. Res. 66, 150-155.

Provenza, F.D., 1995. Role of learning in food preferences in ruminants. Proc. $8^{\text {th }}$ Int. Symp. Ruminant Physiology. Ruminant Physiology: Digestion, Metabolism, Growth and Reproduction. Eds Engelhardt, W.V., Leonhard-Marek, S., Breves, G. \& Giesecke, D., Ferdinand Enke Verlag, Stuttgart, Germany. pp. 233-247.

Pryce, J.D., 1969. Modification of the Barker \& Summerson method for the determination of lactic acid. Analyst 94, 115-1152.

Speijers, M.H.M., Fraser, M.D., Theobald, V.J. \& Haresign, W., 2005. Effects of ensiled forage legumes on performance of store finishing lambs. Anim. Feed Sci. Technol. 120, 203-216.

Suzuki, M. \& Lund, C.W., 1980. Improved gas liquid chromatography for simultaneous determination of volatile fatty acids and lactic acid in silage. J. Agric. Food Chem. 28, 1040-1041.

Taasoli, G. \& Kafilzadeh, F., 2008. Effects of dried and ensiled apple pomace from puree making on performance of finishing lambs. Pakistan J. Biol. Sci. 11 (2), 294-297.

Van Niekerk, W.A., Hassen, A. \& Bechaz, F.M., 2007. Influence of molasses additive and moisture level at ensiling on fermentative characteristics of Panicum maximum. Afr. J. Range For. Sci. 24 (2), 97-102.

Van Soest, P.J., Robertson, J.B. \& Lewis, B.A., 1991. Methods of dietary fiber, neutral detergent fiber, and non-starch polysaccharides in relation to animal nutrition. J. Dairy Sci. 74, 3583-3597.

Weinberg, Z.G. \& Muck, R.E., 1996. New trends in development and use of inoculants for silage. FEMS Microbiol. Rev. 19, 53-68.

Weissbach, F., 1968. Relations between the herbage and the course of fermentation in ensiling green fodder. Habilitation, University of Rostock, Germany.

Wilkinson, J.M., 2005. Silage. Chapter 19: Analysis and clinical assessment of silage. Chalcombe Publications, UK. pp. 198-208.

Yunus, M., Ohba, N., Furuse, M. \& Masuda, Y., 2000. Effects of adding urea and molasses on napier grass silage quality. Asian-Austral. J. Anim. Sci. 13, 1542-1555.

Zobell, D.R., Okine, E.K., Olson, K.C., Wiedmeier, R.D., Goonewardene, L.A. \& Stonecipher, C., 2004. The feasibility of feeding whey silage and effects on production and digestibility in growing cattle. J. Anim. Vet. Advances, 3 (12), 804-809. 